\title{
Kransæðahjáveituaðgerðir í nútíð og fortíð
}

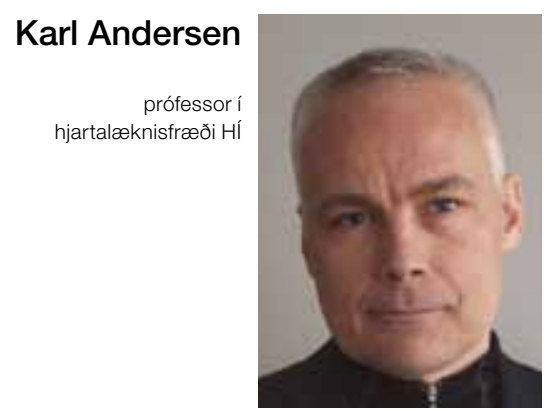

andersen@landspitali.is

Pað ríkti eftirvænting á skurðstofu í Albert Einstein College of Medicine - Bronx Municipal Hospital Center að morgni mánudagsins 2. maí 1960. Sjúklingurinn var 38 ára leigubílstjóri í New York sem hafði pjáđst af illvígum kransæðasjúkdómi, svo slæmum reyndar að hann hafði purft að taka 70-90 nítróglyceríntöflur á dag til að slá á hjartverkinn. Aðgerðin sem var um pað bil að hefjast hafði aldrei áður verið gerð í heiminum. Að baki lágu um 10 ára rannsóknir á hundum par sem tæknin var próuð. Í aðgerðinni var hægri innri brjóstholsslagæð (a. mammaria interna $d x t)$ tengd við hægri kransæð. Petta var fyrsta hjáveituaðgerðin á manni og hún átti eftir að breyta sögu læknisfræðinnar varanlega. ${ }^{1-3}$

Skurðlæknirinn var hinn pýskættaði Dr. Robert H. Goetz sem stóð á fimmtugu. Aðgerð hans pótti tilraunakennd og naut ekki stuðnings hjartalækna eða skurðlækna á peim tíma. Andstaðan var slík að honum var meinað að flytja erindi um aðgerðina á pingi bandarískra brjóstholsskurðlækna um 8 árum síðar með peim rökum að aðgerðin væri ekki mikilvægt framlag og myndi fljótt gleymast. Reyndar fór pað svo að Goetz lýsti ekki aðgerð sinni í læknatímaritum, sjúkraskýrslurnar týndust og öðrum skurðlækni, hinum rússneska Vasilii Kolesov í St. Pétursborg, var eignaður heiðurinn af fyrstu hjáveituaðgerðinni fjórum árum síðar, eða 1964. ${ }^{1-3}$ Рað urðu pví örlög Goetz eins og marga annarra að njóta ekki eldanna sem hann varð fyrstur til að kveikja. Aðgerðartækni Goetz var að vísu nokkuð frábrugðin pví sem síðar varð en engu að síður hafa fáar ef nokkrar aðgerðir nútímalæknisfræði staðist betur tímans tönn en hjáveituaðgerð á kransæðum. Um 800.000 slíkar aðgerðir eru nú gerðar í heiminum á hverju ári.

Kransæðahjáveituaðgerðir hafa verið framkvæmdar á Landspítalanum frá árinu 1986. Í pessu tölublaði Læknablaðsins er lýst árangri pessara aðgerða á 5 ára tímabili, 2002-2006. Petta er mikilvæg samantekt. Í fyrsta lagi gefur hún mikilsverðar upplýsingar frá sjónarhóli gæðamála. Fram kemur að fylgikvillar við pessar aðgerðir eru að flestu leyti sambærilegir við pað sem best pekkist í nágrannalöndunum. Árangur aðgerða, mældur sem lifun, er einnig svipaður. Pessar niðurstöður staðfesta pað að gæði pjónustunnar á Íslandi eru mikil og árangur og fylgikvillar við pessar aðgerðir eru mjög í takt við pað sem gerist á Vesturlöndum.

Niðurstöðurnar eru ekki síður mikilvægar í klínísku samhengi. Algengi gáttatifs eftir hjáveituaðgerðir virðist heldur hátt hér á landi miðað við önnur lönd. Petta gefur tilefni til að leita skýringa, til dæmis í notkun taktstillandi lyfjameðferðar fyrir og eftir pessar aðgerðir. Í ljós kemur að áhættustigun með EuroSCORE gefur sterkastar vísbendingar um dánartíðni við kransæðahjáveituaðgerðir. Pessi niðurstaða parf ekki að koma á óvart par sem EuroSCORE er vel sannreynd alpjóðleg áhættustigun sem tekur til margra undirliggjandi áhættupátta. Lærdómurinn er pó sá að mikilvægt er að taka mið af pessari áhættustigun í undirbúningi fyrir skurðaðgerð hjá öllum sjúklingum sem gangast undir hjáveituaðgerð. Par sem meðalaldur pjóðarinnar hækkar og horfur hjartasjúklinga fara stöðugt batnandi, má búast við að sífellt eldri sjúklingar með lengra genginn sjúkdóm komi til greina í hjáveituaðgerð. Petta getur leitt til pess að meðallifun eftir aðgerð styttist með tímanum, prátt fyrir framfarir í skurðtækni og annarri meðferð. Fróðlegt væri að sjá hvernig EuroSCORE breytist yfir tíma (til dæmis 5 ára tímabil)á peim aldarfjórðungi sem liðinn er frá pví að hjáveituaðgerðir hófust á Íslandi og hvort sú próun endurspeglist í árangri aðgerða.

Ýmis álitamál varðandi aðgerðartækni, notkun taktstillandi lyfja, blóðpynningarlyfja og gjörgæslumeðferð geta haft áhrif á niðurstöður hjáveituaðgerða. Rannsóknir eins og pær sem hér birtast eru nauðsynlegur grundvöllur til pess að meta slíka pætti með pað fyrir augum að tryggja öryggi sjúklinga. Pess vegna ber að fagna rannsókn sem pessari og ástæða er til að hvetja til áframhaldandi vinnu af sama toga. Aðeins með pví móti er unnt að meta hvort fylgt sé alpjóðlegum klínískum leiðbeiningum í starfseminni og greina hugsanleg frávik.

Leigubílstjórinn sem fyrr er getið varð einkennalaus eftir aðgerð Goetz og félaga vorið 1960. Hann sneri aftur til vinnu sinnar en lést af völdum kransæðastíflu rúmu ári síðar. Krufning sýndi að hjáveitutengingin var ennpá opin og starfaði eðlilega.

\section{Heimildir \\ 1. Konstantinov IE. Robert H. Goetz: The Surgeon Who Performed the First Successful Clinical Coronary Artery Bypass Operation. Ann Thorac Surg 2000; 69: 1966-72. \\ 2. Mehta NJ, Khan IA. Cardiology's 10 greatest discoveries of the 20th century. Tex Heart Inst J 2002; 29: 164-71. \\ 3. Haller JD, Olearchyk AS. Correspondence. To the editor. Tex Heart Inst J 2002; 29: 342-3.}

